Article

\title{
Energy Engineering Approach for Rural Areas Cattle Farmers in Bangladesh to Reduce COVID-19 Impact on Food Safety
}

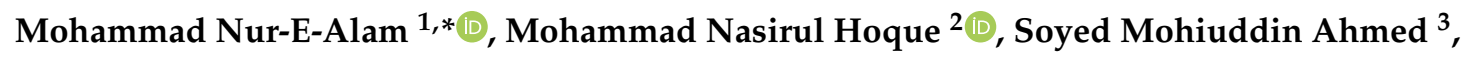 \\ Mohammad Khairul Basher ${ }^{4}$ and Narottam Das ${ }^{5,6}$ (D) \\ 1 Electron Science Research Institute, School of Science, Edith Cowan University, \\ Joondalup, WA 6027, Australia \\ 2 Department of Physics, University of Chittagong, Chattogram 4331, Bangladesh; nasirul@cu.ac.bd \\ 3 School of Pharmacy and Life Science, Jiujiang University, Jiujiang 332000, Jiangxi, China; \\ mohiuddinppqc@yahoo.com \\ 4 Institute of Electronics, AERE, Bangladesh Atomic Energy Commission, Dhaka 1349, Bangladesh; \\ khairulcu@gmail.com \\ 5 School of Engineering and Technology, Central Queensland University, Melbourne, VIC 3000, Australia; \\ n.das@cqu.edu.au \\ 6 Centre for Intelligent Systems, School of Engineering and Technology, Central Queensland University, \\ Brisbane, QLD 4000, Australia \\ * Correspondence: m.nur-e-alam@ecu.edu.au
}

Received: 21 September 2020; Accepted: 11 October 2020; Published: 17 October 2020

\begin{abstract}
This paper reports on the optimization of thin-film coating-assisted, self-sustainable, off-grid hybrid power generation systems for cattle farming in rural areas of Bangladesh. Bangladesh is a lower middle-income country with declining rates of poverty among its 160 million people due to persistent economic growth in conjunction with balanced agricultural improvements. Most of the rural households adopt a mixed farming system by cultivating crops and simultaneously rearing livestock. Among the animals raised, cattle are considered as the most valuable asset for the small-/medium-scale farmers in terms of their meat and milk production. Currently, along with the major health issue, the COVID-19 pandemic is hindering the world's economic growth and has thrust millions into unemployment; Bangladesh is also in this loop. However, natural disasters such as COVID-19 pandemic and floods, largely constrain rural smallholder cattle farmers from climbing out of their poverty. In particular, small- and medium-scale cattle farmers face many issues that obstruct them from taking advantage of market opportunities and imposing a greater burden on their families and incomes. An appropriate measure can give a way to make those cattle farmers' businesses both profitable and sustainable. Optimization of thin-film coating-assisted, self-sustainable, off-grid hybrid power generation system for cattle farming is a new and forward-looking approach for sustainable development of the livestock sector. In this study, we design and optimize a thin-film coating-assisted hybrid (photovoltaic battery generator) power system by using the Hybrid Optimization of Multiple Energy Resources (HOMER, Version 3.14.0) simulation tool. An analysis of the results has suggested that the off-grid hybrid system is more feasible for small- and medium-scale cattle farming systems with long-term sustainability to overcome the significant challenges faced by smallholder cattle farmers in Bangladesh.
\end{abstract}

Keywords: cattle farming; COVID-19 pandemic; economic point of view; food safety; HOMER; hybrid system; smallholder; thin-film coating 


\section{Introduction}

Bangladesh is a small country on the world map; located in south Asia having a land area of 148,460 square kilometers. Apart from the hilly areas, most of the land consists of plains with a strong network of rivers throughout the country. Bangladesh is a small country with a large population, where more than 1085 persons live per square kilometer. Besides industrialization and other commercial infrastructures, agriculture plays the most vital role in the country's economy. Agriculture and livestock not only boost the Gross Domestic Product (GDP), they also ensure food security and help to reduce poverty and unemployment in rural areas. The contribution made by livestock to the GDP for the Fiscal Year 2017-2018 was 1.53\% at a constant price, which was $13.6 \%$ of the total agricultural sector contribution to GDP [1]. Despite achieving improvement in many aspects of food security, the people of Bangladesh still lack dietary diversification, which leads to nutritional imbalance [2]. There is a great discrepancy between demand and production in the case of protein intake. Milk production for the year 2018-2019 was 99.23 lakh Metric Ton against a demand of 152.02 lakh Metric Ton (one lakh is equivalent to 100,000) [3]. On the other hand, many people in rural areas cannot afford to maintain a balanced diet daily. Sustainable and well-distributed livestock farms in different regions of the country not only improve nutrition but are also preferred assets of investment [4]. Cattle farming has a good economic impact in generating income and food security in rural areas which employ about 20\% of the rural labor force [5]. The United Nations Food and Agriculture Organization (FAO) reported that per capita meat consumption in Bangladesh is low (about four kilograms) compared to other neighboring countries such as Pakistan. However, according to the data from the Department of Livestock Services (DLS) Bangladesh, the country's total demand for meat stands at 72.97 lakh tonnes with the requirement of $120 \mathrm{~g}$ of meat per head, almost $55 \%$ of which comes from cows and goats. Besides the regular beef intake, there is a huge need for cows during one of the biggest festivals (Eid-Ul-Adha) of the Muslim calendar. In the past 20 years, Bangladesh has attempted to become fully dependent on domestic production to meet the extra demand for cattle during the Eid-Ul-Adha celebrations due to a drastic reduction in cattle imports from a neighboring country. Twenty years ago, Bangladesh entered a new era introducing professional micro-scale cattle farms to meet the demand of the local market for milk and meat. According to the report published as in Reference [6], 80 to $90 \%$ of the country's cattle production comes from rural farmers with either small- or medium-sized farms. Many people are also currently interested in modern agriculture, including cultivation of fruits, vegetables, fish and cattle as e-commerce has opened a promising platform for the young entrepreneur. Nevertheless, the housing shortage in Bangladesh is a major issue with the result being that many cultivable lands, as well as fields formerly used for open grazing, are nowadays utilized to build new houses and apartments which are reducing the open land areas at an alarming rate in Bangladesh. This is the reason Bangladesh cannot consider an open field cattle farm as found in Australia, New Zealand, or large European countries. Most of the cattle farms (small and medium scale) in Bangladesh either in rural or semi-town areas have very limited land size. Though there are many modern and scientifically advanced tools and equipment widely used in agriculture nowadays in Bangladesh, only a negligible number of farms are to be found using the energy engineering approach to become self-sufficient and sustainable and whilst mitigating the energy costs against the production costs. For the cattle farm, the most challenging part is the meat collection, milk collection, storage and marketing, for which each farm needs high-quality electrical equipment including electric blade, vacuum pump milking parlor systems, and high-performance refrigeration systems. Besides all other costs, such kinds of facilities require a massive budget for energy consumption to regulate as well as maintain adequate temperature, relative humidity, and ventilation. In recent years, energy cost efficiency becomes a key factor for sustainable food and crop storage facilities worldwide, which has stimulated many scientists' enthusiasm to introduce more off-grid, self-sustainable energy-harvesting and saving facilities [7-11]. Hybrid (PV, Wind, Diesel and Battery) power generation systems have recently become very promising for $100 \%$ electrification for the rural or remote island areas. A significant number of research works have been conducted worldwide by researchers and scientists in the field of renewable energy (RE) to 
design and optimize various types of hybrid power generation systems [12-17]. In addition, these types of hybrid power systems can be attractive alternatives for cost-effective power generation in Bangladesh. It is very hard for the government to provide on-going subsidies in power production. Bangladesh has set the goal of becoming a country with zero power supply issues such as daily power cuts, to provide electricity for everyone within the very near future. In support of the country's goal these types of hybrid power systems, together with nano-coated building materials with power-saving features, if used in different infrastructures, can help to reach to the goal of $100 \%$ electrification of the country. Renewable power generation and savings based multi-component hybrid systems can also lower carbon emissions to an acceptable level. The exploration of possible and economically viable renewable energy sources is one of the prime interests of the country's policymakers and research scientists to mitigate the energy demand of the country. However, there are several factors involved in the successful development of new renewable-type energy production systems [18-21]. M. E. Karim et al. has conducted a comprehensive study on the government involvements, legal issues, regulatory measures and the policy aspects related to the renewable energy in Bangladesh [22]. They have reported on the significance having of comprehensive policy initiatives, including active and enhancing government participation on developing RE systems, ensuring localization and easily accessible of RE technology, evaluation of relevant legal policy initiatives and others that can shape the country's sustainable development.

At present, the novel coronavirus (COVID-19) outbreak (first spread in Wuhan, China in late 2019) has resulted in a worldwide severe pandemic that has already disrupted human life and civilization. This coronavirus has already caused a huge number of deaths and becomes a major threat for mostly older people who are suffering from diabetes, cardiovascular disease, cancer, and chronic respiratory syndrome [23]. The world's leading scientists, chemists, microbiologists, engineers, doctors, and other health professionals are working very hard to find proper solutions for this new virus by understanding the nature of COVID-19. There are many predictions available online nowadays about the microstructural properties and weather- and region-dependent nature of COVID-19; however, getting an active vaccine against this virus requires a significant amount of research effort together with on-going worldwide clinical trials. The world is seeking new hope while currently relying on the precautions that have been recommended by the World Health Organization (WHO), including social and physical distancing to control the rapid spread of this virus [24]. The outbreak of COVID-19 has overturned not only human life but also the global economy by seriously affecting all kinds of industries including food, agriculture, readymade garments, leather, building and infrastructure materials, energy and power sectors, science and technology and others all over the world [25-30]. Many industries and businesses were forced to take actions like job cuts, even in some cases shut down completely. As a result, millions previously in the workforce have become jobless, and severely affecting-directly and indirectly-developing countries like Bangladesh. As COVID-19 can transfer easily from one affected person to others (i.e., community transmission), it becomes a great concern how, as well as how long is needed, to get back to normal life. According to the proposal jointly made by WHO and FAO for food safety including multi-agency co-operation, proper inspections in different stages of production can mitigate significantly the spread of this corona-virus but to achieve this is a very much challenging task [31,32]. In these circumstances, the risk of contamination can be minimized and kept under control only if the local demand for foods and protein supply can be met by the local growers and suppliers. In Bangladesh, the well-being of the economic cycle as well as of a large number of the population is mainly dependent on good agricultural and industrial prospects. All agricultural and industrial sectors including garment, leather and industries requiring construction materials are major candidates where continuous electricity supply is needed for maintaining a non-disruptive production cycle for the well-being of the economy. However, currently, these sectors are facing severe problems during the COVID-19 crisis and maintaining a continuous electricity supply will continue to be a major issue for many smallholder farmers in the rural farming and cultivation areas in post-COVID-19 Bangladesh [33-42]. Besides, the national grid electricity supply, solar photovoltaics (PVs)-assisted 
power generation can help all industries and factories to maintain their continuous production cycle. Therefore, designing new and modification of existing infrastructures that can generate and save energy will be the most effective approach for the well-being of post-COVID-19 Bangladesh and will assist in returning the country to a normal lifestyle. In addition, this energy engineering can be a model for future modern farming in any country of the world and, in the near future, potentially can help to diminish the current rise in unemployment due to the COVID-19 pandemic by making all the farms and food industries active and fully productive again.

In this article, we design and optimize a hybrid power generation system that can be applied together with thin-film, low-emissivity (Low-E) coating-assisted, energy-saving features for self-sustainable off-grid or semi-off-grid infrastructure for cattle farmers in rural areas. In Bangladesh, grid connection is not available throughout the country, and there is no alternative of a micro-grid to ensure the power availability to any new or existing infrastructures for farming and food storage. However, the implementation of modern scientific processes can increase the production levels by up to $50 \%$, whereas if the conventional power sources are used, the fuel cost will have a negative impact on profit margins. The organization of this paper is as follows: Section 2 briefly describes the materials and methods, where we describe the types of farms targeted and ways of power optimization. Section 3 describes in detail the means of engineering of energy generation and savings including the components that are considered in this work. Section 4 presents the optimized simulation results, and Section 5 includes a short discussion based on the outcome of the hybrid energy engineering optimization, followed by a conclusion in Section 6 .

\section{Materials and Methods}

\subsection{Types of Farm}

Figure 1 shows the images of mostly available (typical house type) infrastructure in Bangladesh for limited land size cattle farms together with the schematic diagram of a proposed cattle house containing hybrid power generation systems, in conjunction with energy-saving, thin-film-coated roof materials. A thin-film coating, mainly the low-E coating-assisted roof material, can filter daytime sun irradiation. The low-E-coated glass becomes a modern day building material towards the development of net-zero building infrastructures. Low-E coatings are designed to filter the visible spectrum whilst reflecting the infrared (IR) spectrum, thus reducing the heat entering the building [43-47]. Most of the commercially available low-E coatings are glass-based; however, several companies have developed low-E-type coatings on very thin polycarbonate (clear plastic substrate) materials that can be retrofitted to any transparent material, including glass or Perspex. In our proposed cattle house (Figure 1b), rather than a clear polycarbonate roof material, we are introducing a low-E-type coated semitransparent roof material which will allow only the visible light and thus will not only save lighting costs but also reduce the heat by reflecting the IR spectrum (which is mainly heat) during the day time. The effectiveness of thin-film coatings on energy savings is detailed in the Section 3.4.

In order to study the economic feasibility of energy engineering aspects, various types of cattle farms categorized by size, were considered such as small, medium and large farms holding the land size of 0.5 to 2.0, 2.1 to 5.0, and above 5.0 acres, respectively. However, the details information about the land size and the number maximum animals in one row or column are preciously provided in the following Refs. [48,49]. Table 1 presents the criteria for different types of the farm used in this study. 


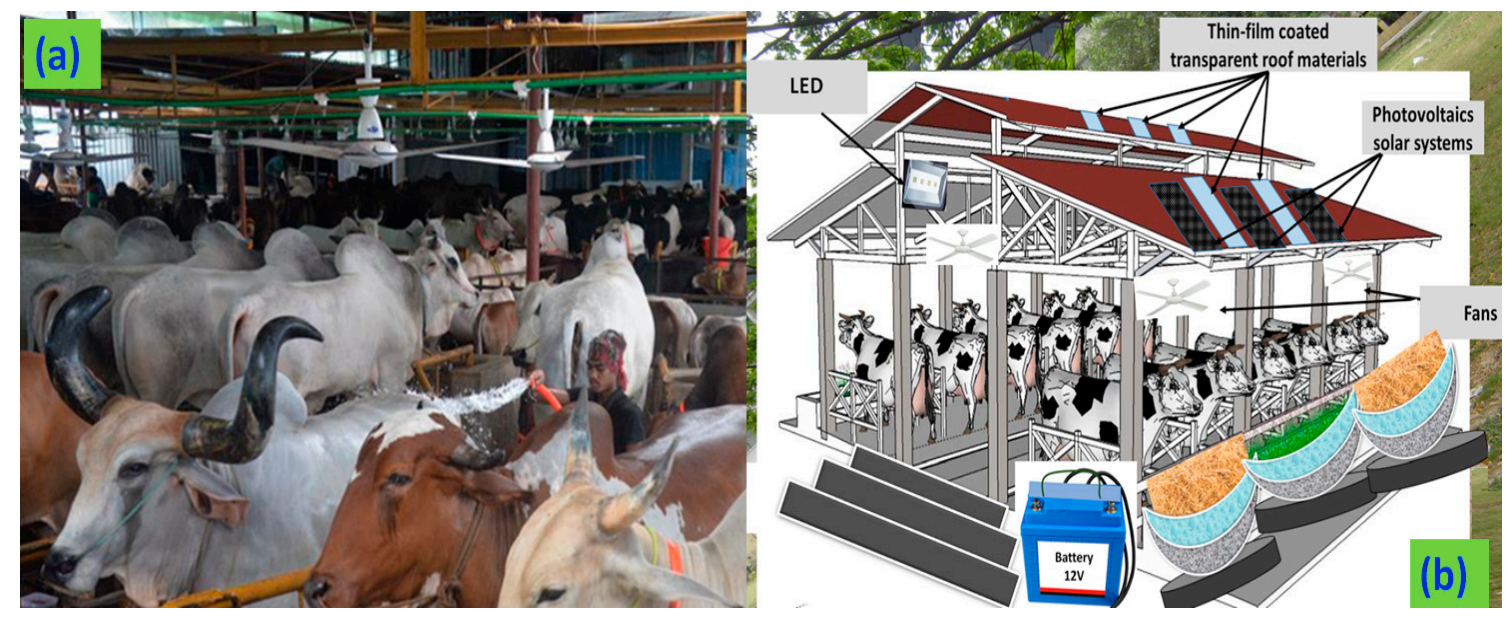

Figure 1. Images of a cattle farms. Existing typical cattle house in Bangladesh (a), and the schematic diagram of a proposed cattle house that contains hybrid power generation systems, together with energy-saving thin-film-coated roof materials (b).

Table 1. Criteria of different types of cattle farm (in terms of the number of cows).

\begin{tabular}{ccccc}
\hline \multirow{2}{*}{ Particular } & Unit & \multicolumn{3}{c}{ Herd Size } \\
\cline { 3 - 5 } & & Small & Medium & Large \\
\hline Area of the farm & Acre & 0.5 to 2.0 & 2.1 to 5.0 & Above 5.0 \\
$\begin{array}{c}\text { Head count of milking cows } \\
\text { Head count of milking cows for } \\
\text { this study }\end{array}$ & Number & 5 to 20 & 21 to 50 & Above 50 \\
Shed area & Number & 13 & 35 & 100 \\
& Row shape & Single row & Double row & Separate shed \\
\hline
\end{tabular}

\subsection{Optimization of a Power-Generating System}

We aimed to find a feasible and sustainable energy generating system that can meet the energy demand in cattle farming for the rural areas in Bangladesh. The PV systems are considered as the best renewable energy resources due to the great advantages that solar cells/module does not require any raw material to feed and have a very low operation and maintenance cost with a long-term operational life. However, the drawback for using solar cell is that it depends on sunlight and when sunlight is not available (such as a rainy and cloudy day or night) the energy extraction is greatly hampered. The PV module can be used only during the daytime with clear sky (i.e., a sunny day) thus confirms the unsuitability of use for the microgrid system. However, a storage device such as the battery can solve the problem by storing the unused excess power and fed to the load when it requires. Therefore, the PV-battery system can be a sustainable solution to meet the demand of a cattle farm. Techno-economic analyses for different energy (single generator, PV-Battery and PV-Generator-Battery hybrid) systems were carried out to find the most convenient and economically feasible microgrid system. Hybrid Optimization of Multiple Energy Resources (HOMER) software, developed by National Renewable Energy Limited (NREL, Boulder, CO, USA) is used to optimize the hybrid power systems. HOMER simulation tool allows comparing various types of systems in combination with capital, maintenance and other types with a given energy resource to meet the system load demand. Figure 2 shows the schematic diagram of HOMER algorithm that used in this work, where a sustainable power source is designed by considering PV cells, storage device, diesel generator, converter and other appropriate devices. 


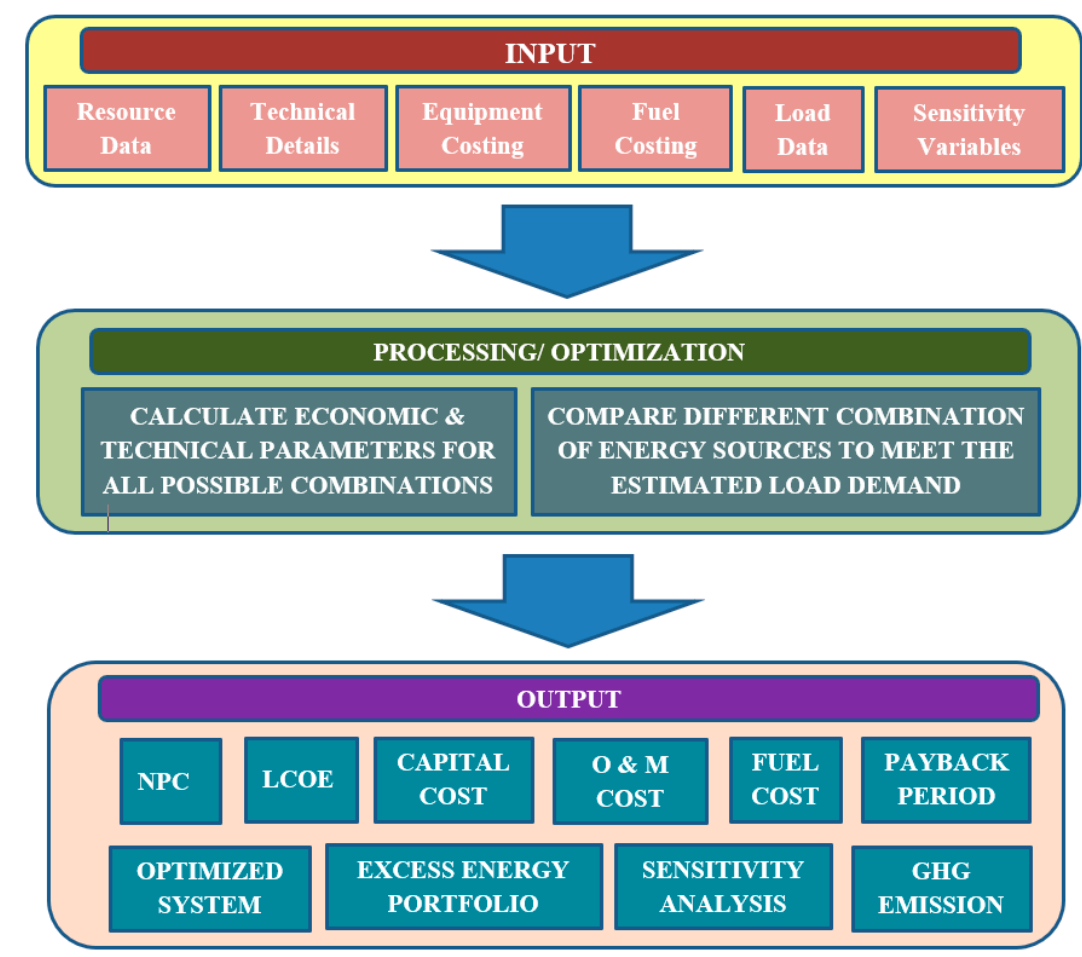

Figure 2. Schematic diagram of Hybrid Optimization of Multiple Energy Resources (HOMER) algorithm.

In this module, the available renewable energy resources and load profile for the system are required to set as input. Besides this, for the cost calculation, the price and operational datasheet need to be supplied for PV, Battery, Converter, generator and other devices. The economic analysis performed using the HOMER software for different types of farms with the payback period and energy engineering are detailed in the next section.

\section{Engineering of Energy Generation and Savings}

\subsection{Design, Components and Optimization of Hybrid Power Generation System}

\subsubsection{Solar Radiation Data}

The solar data available in HOMER pro software was used in this study which was originally extracted from the NASA surface meteorology and Solar energy database. The clearness index defines as the fraction of transmitted solar radiation through the atmosphere to the Earth surface is also an important parameter for HOMER Pro simulation tool. The clearness index is a dimensionless unit which varies from 0 to 1 . For a clear sky, the index is close to 1 whereas close to zero for a dense cloud condition. The monthly solar radiation with a clearness index for Bangladesh is shown in Figure 3. It can be seen that the average daily solar radiation is maximum in April while the clearness index is maximum in December. It is because April is the summer when the sun is tilted to the northern hemisphere and at that time the sky becomes cloudy. On the other hand, in winter (December and January), the length of the day is comparatively shorter, and the sun is tilted to the southern hemisphere. However, at this time the sky is clear due to low humidity. 


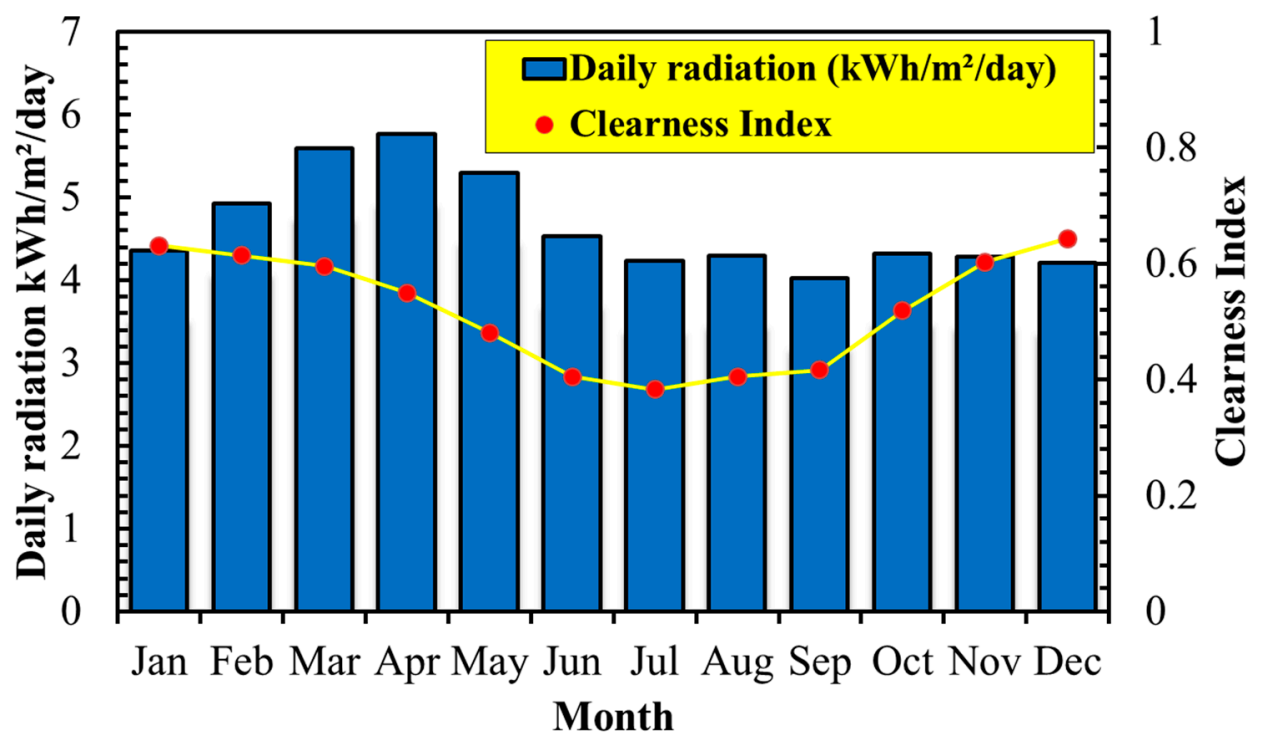

Figure 3. Monthly average solar radiation for a year.

\subsubsection{Load Consumption Analysis}

Load consumption is the most important part of any power system. The load consumption profile indicates the variation of load demand in different time of the day, month and season. This profile completely depends on the nature of the system. Keown et al. [50] reported that if the temperature rises above $80^{\circ} \mathrm{F}\left(26^{\circ} \mathrm{C}\right)$, feed intake by the cattle reduced significantly and thus impacts their growth. Additionally, at $90^{\circ} \mathrm{F}\left(32^{\circ} \mathrm{C}\right)$ or above, the milk production reduces by at least 3 to $20 \%$. Therefore, a convenient and comfortable atmosphere is necessary to maintain for the maximum production. For the medium and small farm energy is required only for lighting and ventilation, but for the large farm milk collection and storage device are considered as additional load along with lighting and ventilation system.

For a large cattle farm, the most challenging period is to collect a huge amount of milk and marketing it instantly. For this reason, a large cattle farm should have a milking parlor and refrigeration system. G. Todde et al. shows that the power rating of the vacuum pump for each milking cow is $75 \mathrm{~W}$ [51]. A cow has to go to the milking parlor twice a day and on an average, it takes 15-20 min for milking. Therefore, the daily power requirement for milk collection is given by,

$$
75 \mathrm{~W} \times 20 \mathrm{~min} \times 2 \text { times } \times 100 \text { cows } / 1000 \times 60=5 \mathrm{kWh}
$$

On the other hand, the liquid milk leaves the cow at $38^{\circ} \mathrm{C}$ and requires cooling at $4{ }^{\circ} \mathrm{C}$ to avoid milk spoil. To prevent the bacteria growth, the milk should maintain 38 to $10^{\circ} \mathrm{C}$ during the first hour after collection and from 10 to $4.4{ }^{\circ} \mathrm{C}$ during the second hour [52,53]. Upton et al. [54] reveals that the consumed electricity for milk cooling system is $13.02 \mathrm{Wh} / \mathrm{L}$. If we consider the daily average milk production per cow is $15 \mathrm{~L}$, then the daily power consumption for refrigeration can be calculated as follows:

$$
15 \mathrm{~L} \times 100 \text { cows } \times 13.02 \mathrm{Wh} / \mathrm{L} / 1000 \times 24=0.81 \mathrm{kWh}
$$

Inside the cowshed, proper lighting and ventilation system required for a healthy environment for the cattle. In Bangladesh, the average temperature is $32{ }^{\circ} \mathrm{C}$ in summer. In this study, LED lights and ceiling fans are considered for lighting and ventilation system. Table 2 shows the power rating and appropriate combination for different types of the farm are given below. 
Table 2. Power rating, the combination of lighting, and ventilation devices for different types of farm.

\begin{tabular}{ccccc}
\hline \multirow{2}{*}{ Particular } & \multirow{2}{*}{ Power Rating (W) } & \multicolumn{3}{c}{ No. of the Unit for Different Types of Farm } \\
\cline { 3 - 5 } & & Small & Medium & Large \\
\hline LED Light & 15 & 6 & 16 & 40 \\
Fan & 80 & 6 & 16 & 40 \\
\hline
\end{tabular}

Figure 4 shows the differences in load consumption for three different types of farms, where it can be seen that the cattle farm load stays at the minimum stage in the winter season (November to February). This is because, in the winter season, the cooling system is not necessary for the farm. At night, there is hardly any load for the small- and medium-sized farm except lighting. On the other hand, the large farm has to switch on the refrigerator to store milk and, as a result, it requires a load consumption of more than $30 \mathrm{~kW}$ during the winter season. In March and October, the load demand is at a moderate stage. During this time, the temperature at night in such a state that the cooling system is not required for the cowshed. However, during the daytime, fans are needed to be switched on. At the summer season (April to September), there is a huge chance of heatstroke for the cows. In order to stabilize the production of milk, an additional $24 \mathrm{~h}$ cooling system needs to be implemented. This $24 \mathrm{~h}$ cooling system consisted of a ceiling fan is the major challenge to meet the demand for energy supply. During the summer season, the load demand is maximum for all types of farms due to ensure a congenial environment inside the shed.

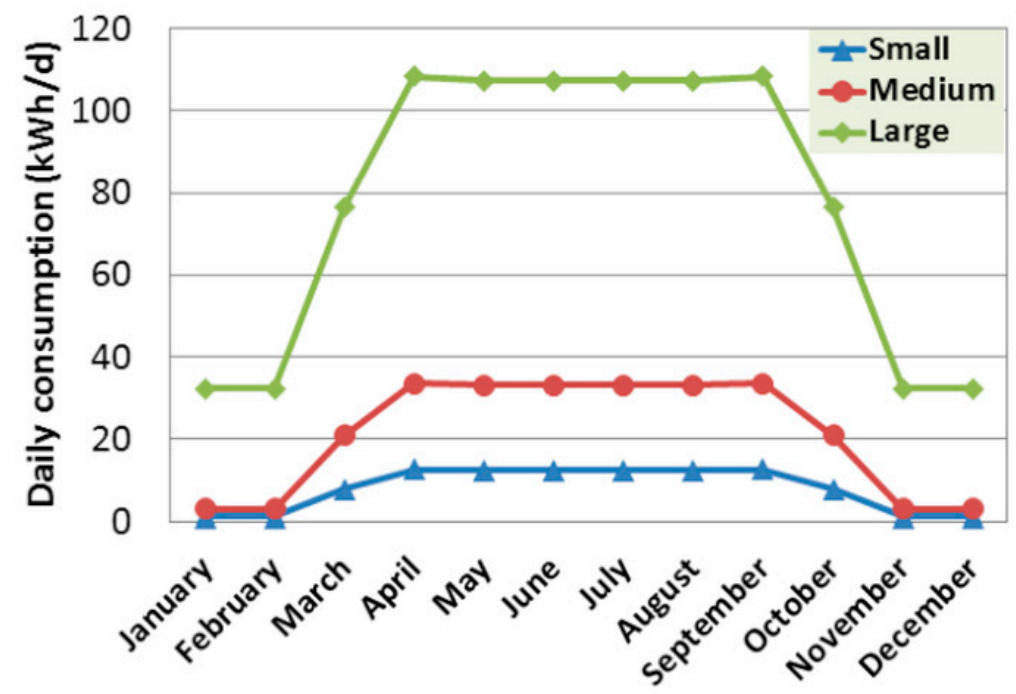

Figure 4. Monthly load profile for different types of farm.

\subsection{System Components}

\subsubsection{Solar-PV Module}

Polycrystalline silicon PV panels are considered to perform the simulation process in this study. Considering the relation between the orientation of the solar panels and PV output; the PV panels are considered to be placed with south facing and a slope of about 22 degrees with earth surface. In this case, the temperature effect of the solar cell is neglected. The estimated primary cost of PV module is \$USD 1720/kWh including transport and installation cost. The replacement cost of the module is \$USD $1720 / \mathrm{kWh}$ considering the lifetime of about 25 years.

\subsubsection{Battery}

The battery is a commonly used storage device for electrical energy. We consider a $12 \mathrm{~V}$ Lead Acid-type battery for running the simulation optimization. The primary installation cost of this storage 
equipment is \$USD 300/battery, whereas the replacement cost is \$USD 3000/battery. The potential technical parameters for the battery are listed in Table 3.

Table 3. List of the technical parameters of the proposed battery.

\begin{tabular}{ccc}
\hline Criteria & Unit & Values \\
\hline Nominal voltage & $\mathrm{V}$ & 12 \\
Nominal capacity & $\mathrm{kWh}$ & 1 \\
Maximum capacity & $\mathrm{Ah}$ & 83.4 \\
Capacity ratio & - & 0.403 \\
Rate constant & $1 / \mathrm{hr}$ & 0.827 \\
Round trip efficiency & $\%$ & 80 \\
Maximum charge current & $\mathrm{A}$ & 16.7 \\
Maximum discharge current & $\mathrm{A}$ & 24.3 \\
Maximum charge rate & $\mathrm{A} / \mathrm{Ah}$ & 1 \\
Lifetime & Years & 10 \\
Throughput & $\mathrm{kWh}$ & 800 \\
Initial state of charge & $\%$ & 100 \\
Minimum state of charge & $\%$ & 20 \\
\hline
\end{tabular}

\subsubsection{Converter}

A converter is used to convert an electrical signal from alternating current (AC) to direct current (DC) or else vice-versa. A converter is a combination of inverter and rectifier. A PV module produces DC and diesel generator supply AC to serve AC load. Therefore, to synchronize these signals for charging along with supply to the load, a converter is prerequisite for a hybrid power system. The estimated primary installation cost of the converter is $\$$ USD 300/kW and the replacement cost is $\$ U S D 300 / \mathrm{kW}$. Table 4 presents the summarized technical parameters for the inverter and rectifier module.

Table 4. Summary of technical parameters of the proposed inverter and rectifier module.

\begin{tabular}{|c|c|c|c|}
\hline & Criteria & Unit & Values \\
\hline \multirow{2}{*}{ Inverter } & Lifetime & Year & 15 \\
\hline & Efficiency & $\%$ & 95 \\
\hline \multirow{2}{*}{ Rectifier } & Capacity relative to inverter & $\%$ & 100 \\
\hline & Efficiency & $\%$ & 95 \\
\hline
\end{tabular}

\subsubsection{Diesel Generator}

A diesel generator is a conventional power source which converts the chemical energy of diesel into the electric energy. The initial capital cost of the generator is $\$$ USD $500 / \mathrm{kW}$ with an operational and maintenance cost is \$USD 0.030/operational hour. The replacement cost of the diesel generator is \$USD 500/kWh. According to the present market value of Bangladesh, the fuel cost is assumed to be \$USD 0.77/L (BDT 65). Technical specification of the diesel generator is summarized in Table 5.

Table 5. Summarized technical specification of the diesel generator.

\begin{tabular}{ccc}
\hline Criteria & Unit & Values \\
\hline Fuel curve intercept & $\mathrm{L} / \mathrm{hr}$ & 0.838 \\
Fuel curve slope & $\mathrm{L} / \mathrm{hr} / \mathrm{kW}$ & 0.236 \\
Lifetime & Hours & \\
\hline
\end{tabular}

\subsection{Sensitivity Analysis}

A sensitivity variable is a combination of a set of variables for which the HOMER software simulates technical and economic analysis. The incident sunshine is not the same and it varies time to 
time and place to place from the average value. Again, the levelized cost of energy (LCOE) and net present cost (NPC) depend on load profile and project lifetime. For each sensitivity case, HOMER does search for the cost-effective (lowest cost) system in their respective search limit. In this system, the considered sensitive cases are enlisted in Table 6.

Table 6. List of sensitivity variables.

\begin{tabular}{|c|c|c|}
\hline Scaled Average Load (kWh/day) & Project Lifetime (year) & $\begin{array}{c}\text { Solar Scaled Average } \\
\left(\mathrm{kWh} / \mathrm{m}^{2} / \text { day }\right)\end{array}$ \\
\hline Small $(5,7.97,10)$ & 10 & 4.00 \\
\hline Medium $(10,21.24,30)$ & 15 & 4.65 \\
\hline \multirow[t]{4}{*}{ Large $(50,77.55,100)$} & 25 & 5.00 \\
\hline & & 5.50 \\
\hline & & 6.00 \\
\hline & & 6.50 \\
\hline
\end{tabular}

\subsection{Thin-Film Low-E-Type Coatings for Energy Savings}

Most of the low-E-type coatings are mainly structured in a sequence of Dielectric/Metal/Dielectric (DMD) type multilayer containing either single or multiple metal layers. The DMD types thin-film multilayers have been studied extensively due to their promising application potentials in various fields including transparent heat regulation (THR). There are some examples of various DMD structure designs and their fabrication technologies are reviewed and listed in Ref [55]. Figure 5 demonstrates the example of clear and semi-transparent polycarbonate roof materials (Figure $5 a, b$ ) together with the details explanation of solar radiation spectrum and optical properties of different types of low-E-type coatings (Figure $5 c, d$ ). It can be noticed that the polycarbonate roof sheets are, though, suitable for industrial and agricultural purposes; however, they are not capable to filter the solar IR radiation which is mainly heat. The transmission spectral response curves presented in Figure $5 \mathrm{~d}$ confirms the possible rejection of the IR spectrum mostly over $90 \%$. It is said that $43 \%$ of heat is accumulated by the IR spectrum of the sunlight, so by using low-E-type coatings nearly $38 \%$ of solar heat can be controlled.
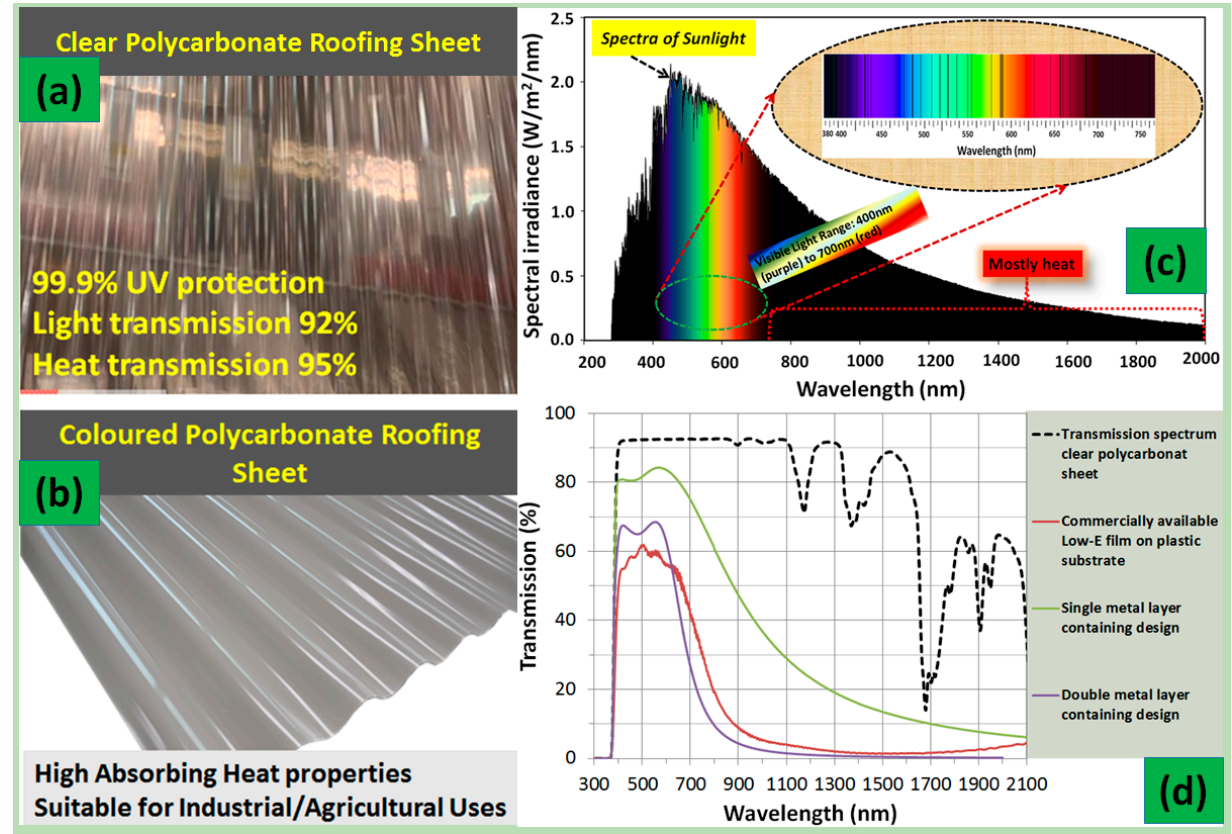

Figure 5. Example of clear and semi-transparent polycarbonate roof materials $(\mathbf{a}, \mathbf{b})$, spectra of sunlight (c) and optical properties of different types of low-E-type coatings compare to that of clear polycarbonate roof materials (d). 
From the spectral response and solar radiation filtering performance (Figure 6), it is very clear that the transparent polycarbonate roof material does not bock any IR spectral radiation of sunlight, while the commercially available low-E-type, thin-film coating and even randomly designed a double metal layer containing DMD type thin-film coating can significantly reduce the radiant heat transmission of sun's spectra into the internal space for any infrastructures. Nur-E-Alam et al., reported that only $29 \%$ of solar IR heat (in between 780 to $1700 \mathrm{~nm}$ spectral region) can pass through a single metallic nano-composite layer contained DMD type coated glass [55]. Figure 6a shows the standardized spectral power density distribution of solar irradiation (AM 1.5 G) while Figure $6 \mathrm{~b}$ represents the power density of solar radiation of filtered (through the clear polycarbonate sheet and several thin-film coatings) transmission spectra.
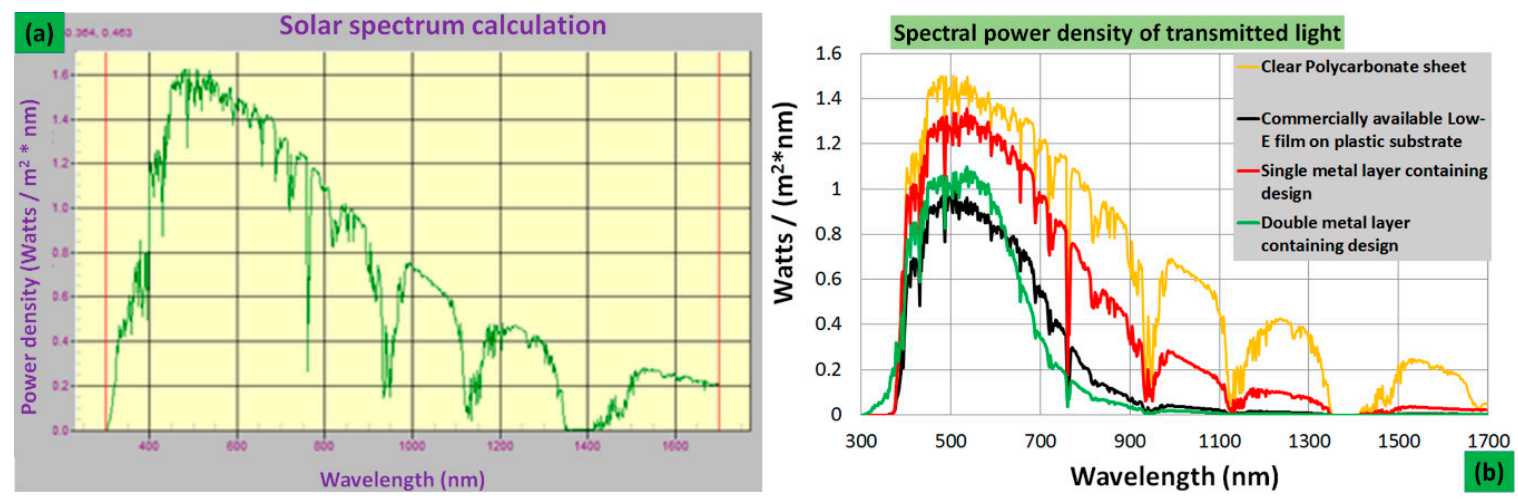

Figure 6. Solar spectrum calculation results in terms of the filtered spectrum of clear polycarbonate roof material and couple low-E-type thin-film coatings.

Overall, features of thin-film coatings clearly indicate that thin-film-coated transparent or semitransparent construction materials (roof or sidewall) can be an additive to save energy for any type of infrastructures for sustainable green earth.

\section{Results}

In this study based on the volume of the farm, we categorize the cattle farms into three different types, such as small, medium and large. In order to investigate the economic feasibility among the farms, we compare the optimized economic parameters for each type which is optimized by the HOMER pro software. The optimized equipment combination and basic economic parameter for each corresponding farm types are summarized in Table 7.

Table 7. Optimize combination of PV, generator and battery for hybrid system.

\begin{tabular}{cccccccccc}
\hline $\begin{array}{c}\text { Types } \\
\text { of } \\
\text { the Farm }\end{array}$ & $\begin{array}{c}\text { PV } \\
\mathbf{( k W )}\end{array}$ & $\begin{array}{c}\text { Generator } \\
\mathbf{( k W )}\end{array}$ & $\begin{array}{c}\text { Battery } \\
\text { (Number) }\end{array}$ & $\begin{array}{c}\text { Converter } \\
\mathbf{( k W )}\end{array}$ & $\begin{array}{c}\text { NPC } \\
\text { (\$USD) }\end{array}$ & $\begin{array}{c}\text { Initial } \\
\text { Capital } \\
\text { (\$USD) }\end{array}$ & $\begin{array}{c}\text { O \&M } \\
\text { (\$USD/ } \\
\text { Year) }\end{array}$ & $\begin{array}{c}\text { LCOE } \\
\text { (\$USD) }\end{array}$ & $\begin{array}{c}\text { Payback } \\
\text { Period } \\
\text { (Years) }\end{array}$ \\
\hline Small & 1.39 & 1.40 & 3 & 0.774 & 9703 & 4227 & 740 & 0.451 & 4.7 \\
Medium & 4.06 & 4.10 & 7 & 2.13 & 26,806 & 11,767 & 2032 & 0.467 & 4.6 \\
Large & 13.10 & 16.0 & 40 & 7.73 & 104,092 & 44,922 & 7995 & 0.508 & 3.3 \\
\hline
\end{tabular}

Figure 7 presents the cost analysis for different types of farms with three different energy source systems. It can be seen that the capital cost increases for a three power source component contained (PV, generator and battery) hybrid system compared to the single component (i.e., generator only) power system and a double power source component (i.e., PV and generator) hybrid system. However, the total cost is low for a three-power-source component-contained ( $\mathrm{PV}$, generator and battery) hybrid system due to low fuel consumption. It indicates that fuel cost is drastically reduced for PV, generator 
and battery hybrid system. Besides, this operation and maintenance cost is also low for this system due to reduced operation hour of the generator.

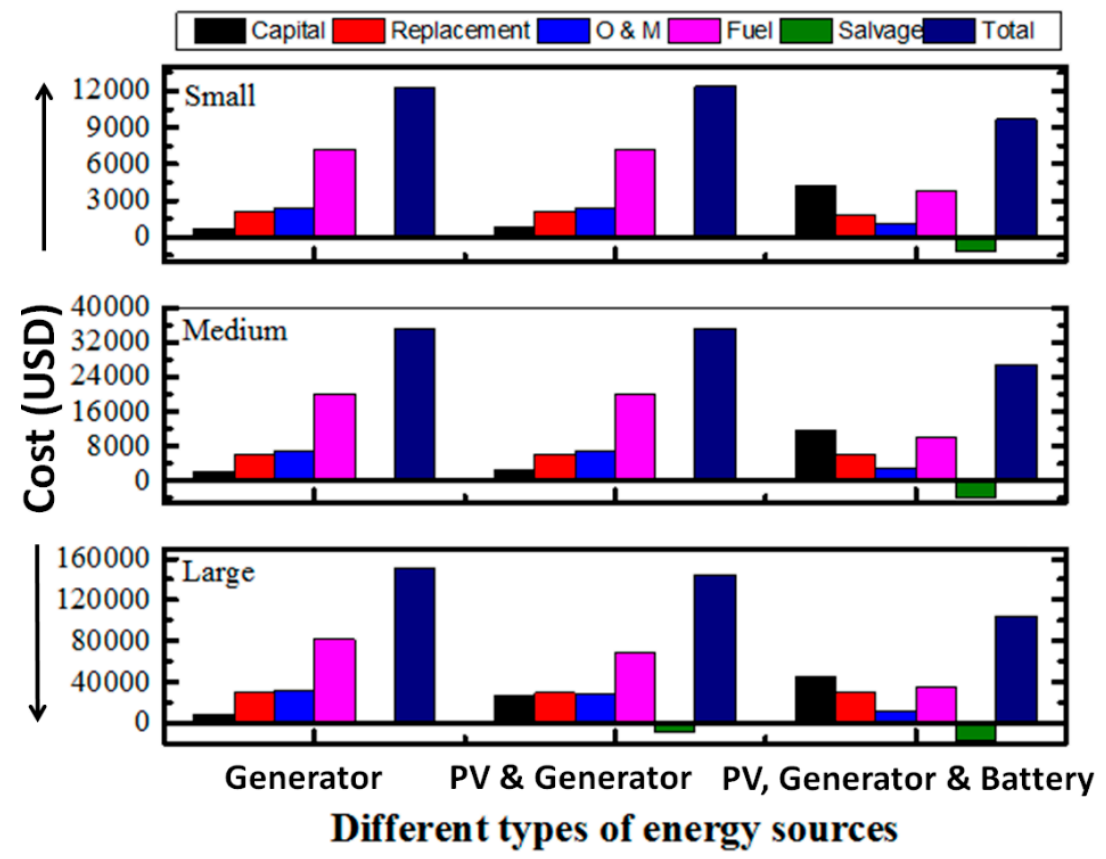

Figure 7. Cost analysis for different types of energy sources.

We have also noticed that the LOCE is smaller for the PV, generator and battery hybrid system compared to that of generator alone or PV and generator system. Comparison of LCOE for different types of farm based on the different combinations of power systems is plotted in Figure 8. The LOCE for generator only and PV and generator hybrid system are almost the same for the small- and medium-sized farms, but for the large farm, the LOCE for PV and generator system is low. On the other hand, the LOCE for PV, generator and battery hybrid system for a small farm is comparatively lower than that of the medium and large farm.

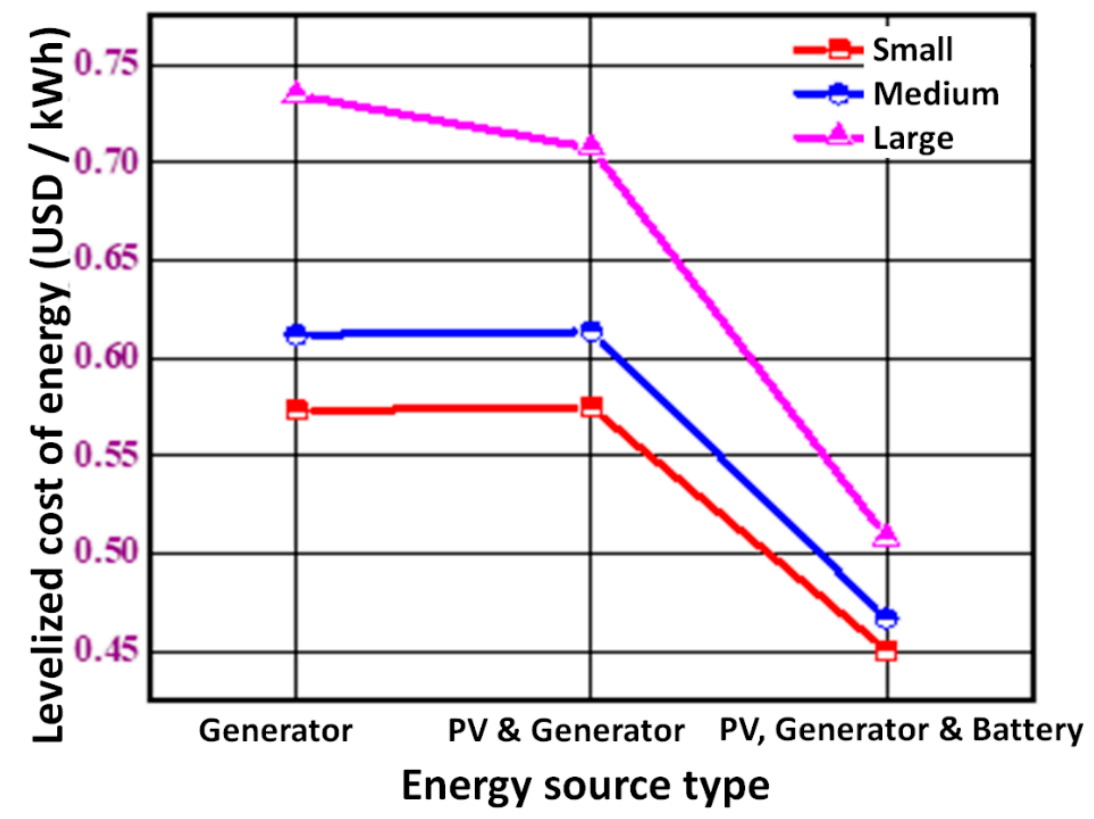

Figure 8. Comparison of the LCOE for different types of farm. 
Figure 9 presents a glimpse of global solar radiation and possible output power that could be generated from the solar spectrum. Hourly variation of solar energy, as well as the output power from a solar cell (Figure 9a), states that the power generation from PV plate is directly proportional to the incident global radiation at a particular place. At noon, the global solar radiation is optimum and at that time the production of electricity from the PV cell is optimum as well. The foremost downside of the solar cell is that it can produce energy only at daytime and it reaches its peak for a very short time duration. During the night and a cloudy day, solar module spends its ideal time without producing any energy.
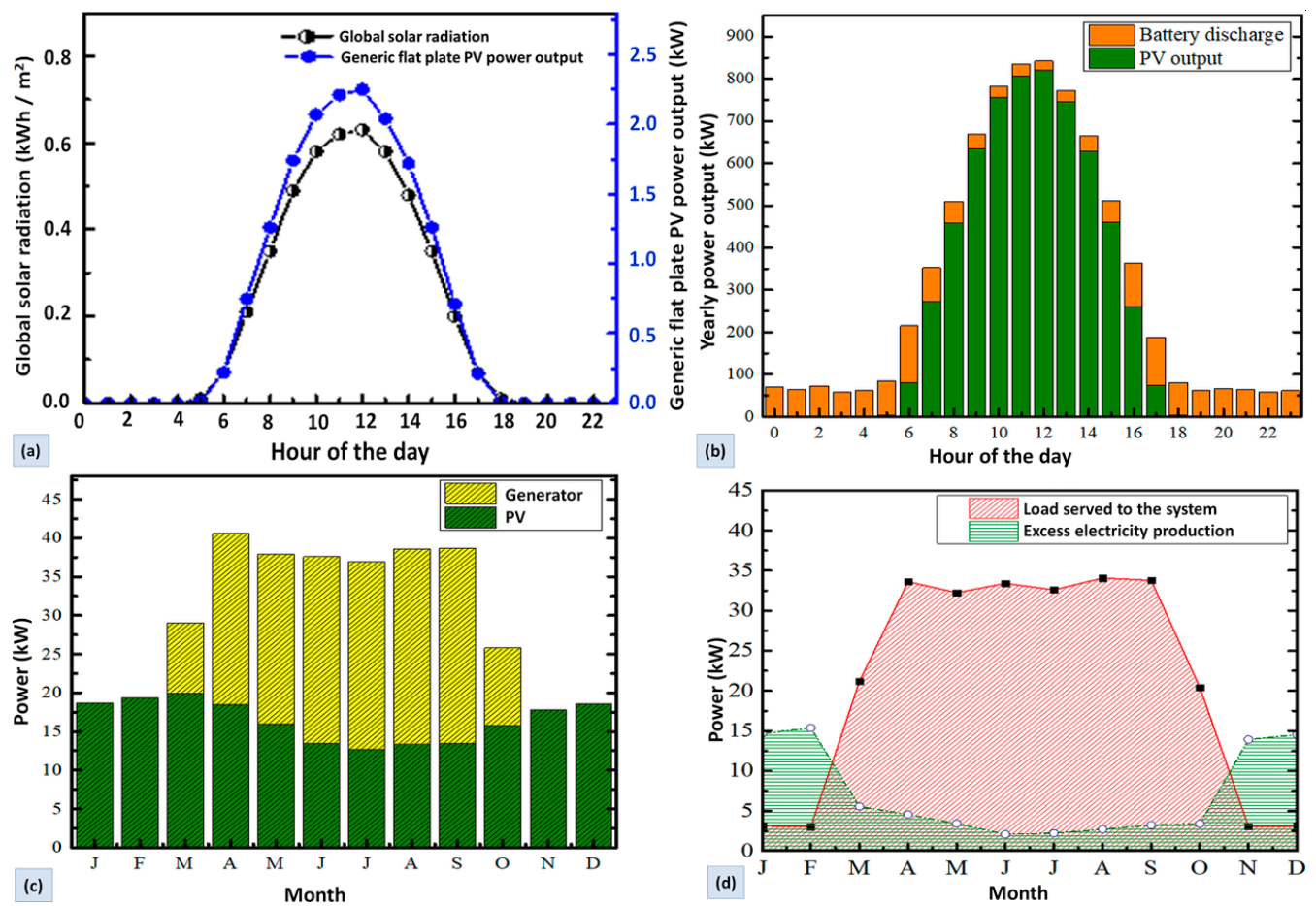

Figure 9. Hourly variation of solar energy as well as the output power from the solar cell (a), an hourly variation of the PV output and battery discharge ratio for an optimized system for the medium-sized farm (b), monthly variation of PV and generator output pattern for optimized power system for medium-sized farm (c), and monthly variation of load demand and excess electricity production for a medium-sized farm $(\mathbf{d})$.

Since the solar cell periodically produces energy and it cannot be controlled manually, a storage device can increase the efficiency of the system. From Figure 9b, it is clear that, during the daytime, the power output from the solar cell is optimum and, at night, when the sun is not available, the battery unit fed power to the system as a power source. The storage device can do back up for all time respective to its capacity. As a result, a continuous power source can be ensured by the PV and battery arrangement. Figure $9 \mathrm{c}$ shows that there is no need to use the generator at the winter season i.e., during November to February of the year in Bangladesh. During this time, the power generation from the solar cell and battery backup are sufficient to fulfil the load demand. On the other hand, the power generation from the solar cell during July (which is a rainy month in Bangladesh) is minimum (Figure 9c) due to the cloudy sky and solar power is not available as a rainy day as well. However, the load consumption remains at the maximum stage. As a result, to meet the electricity demand, the generator must supply the maximum amount of electricity at the same time. Whilst Figure $9 \mathrm{~d}$ shows that the PV, generator and battery system produced excess energy during the winter season. At that time, the load demand is minimum and the production of electricity from PV panel excess the load demand. However, from April to October the load demand is maximum and at that time the production of excess electricity is minimum. 
Figure 10 represents the average load, solar radiation and project life dependent variation of the LCOE. It can be seen (Figure 10a) that the LCOE decreases for the increases in load consumption for all types of farm. In this study, the baseline load for small-, medium- and large-sized farms are $7.97,21.24$ and $75.8 \mathrm{kWh}$, respectively. This graph shows that if all other parameters are fixed when the projected load is lower than the baseline load demand then the LCOE increases with decrease in load. On the other hand, if the load demand increase from the baseline load demand, the LCOE decreases with the load. However, the line for below the baseline load is stiffer than the line for higher load. It means that if the load demands decrease, the LCOE increases abruptly. However, if the load demand increases, the LCOE decreases at a slower rate.
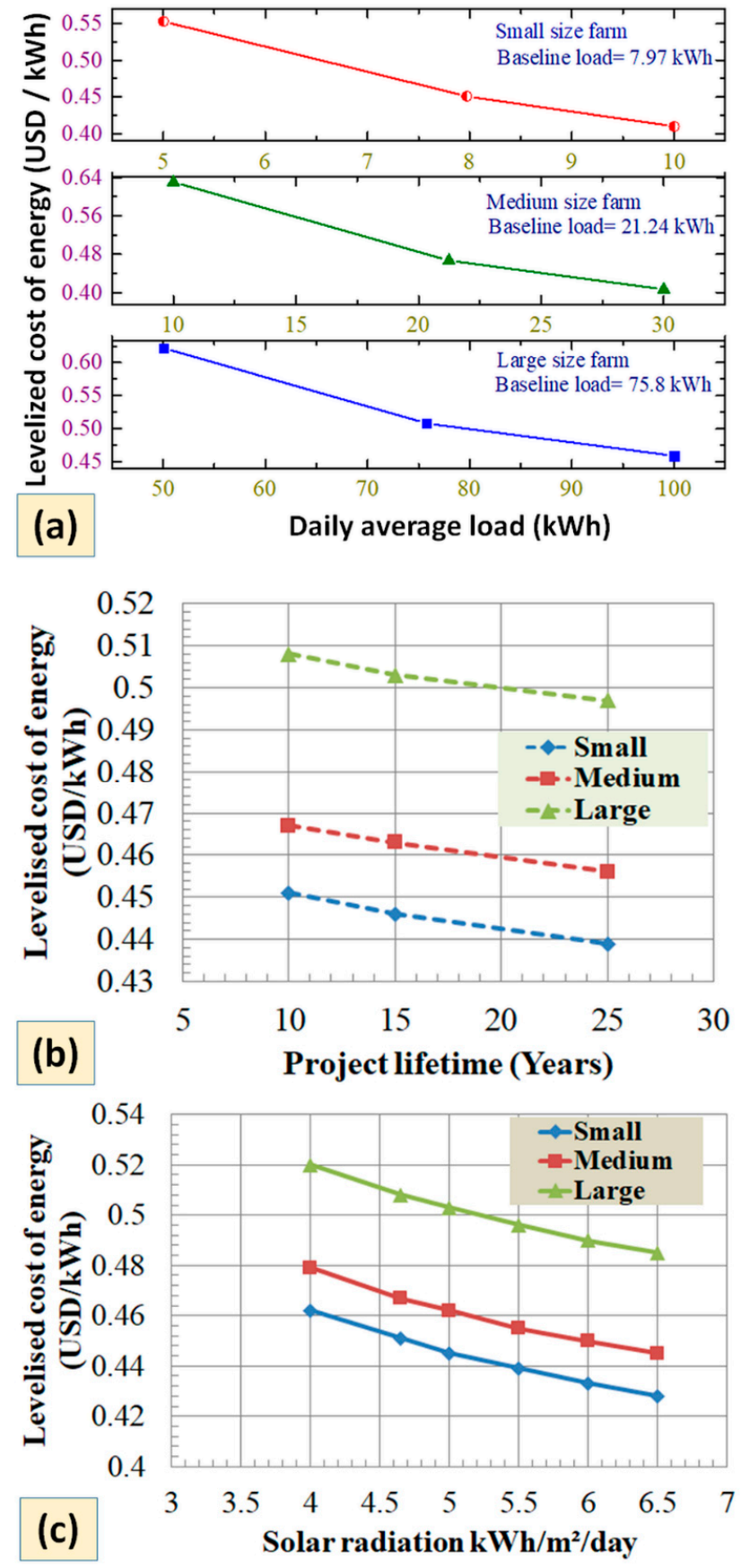

Figure 10. The relation between load and the LCOE for different types of the farm (a), a variation of LCOE with projected lifetime for PV, generator and battery hybrid system (b), and variation of LCOE with incident solar radiation for PV, generator and battery hybrid system (c). 
It can be noticed that the LCOE decreases with an increase in project lifetime for all types of farm (Figure 10b). The PV panel is a sustainable energy source, and it can produce energy for a long time without major maintenance thus diminishes the capital cost significantly for a long-term project. The LCOE has a negative correlation with incident solar radiation. On the other hand, it can be seen (Figure 10c) that the LCOE decreases with the increase of incident solar radiation. When the incident solar energy is increasing, the PV output power is also increasing. Since solar energy is a renewable source and it has no fuel cost, the more contribution of PV power over generator will decrease the overall energy cost.

Figure 11 shows that difference of greenhouse gas $\left(\mathrm{CO}_{2}\right)$ emission from the generator, and PV and generator type energy sources are negligible for the small and medium farm. However, they have an abrupt decrease in $\mathrm{CO}_{2}$ emissions for $\mathrm{PV}$, generator and battery hybrid systems. On the other hand, for a large farm, greenhouse gas emissions reduce chronologically for the generator, PV and generator, and PV, generator and battery system. Finally, it can be concluded that based on the greenhouse gas emission, PV, generator and battery hybrid system is more feasible than any other two types of farms.

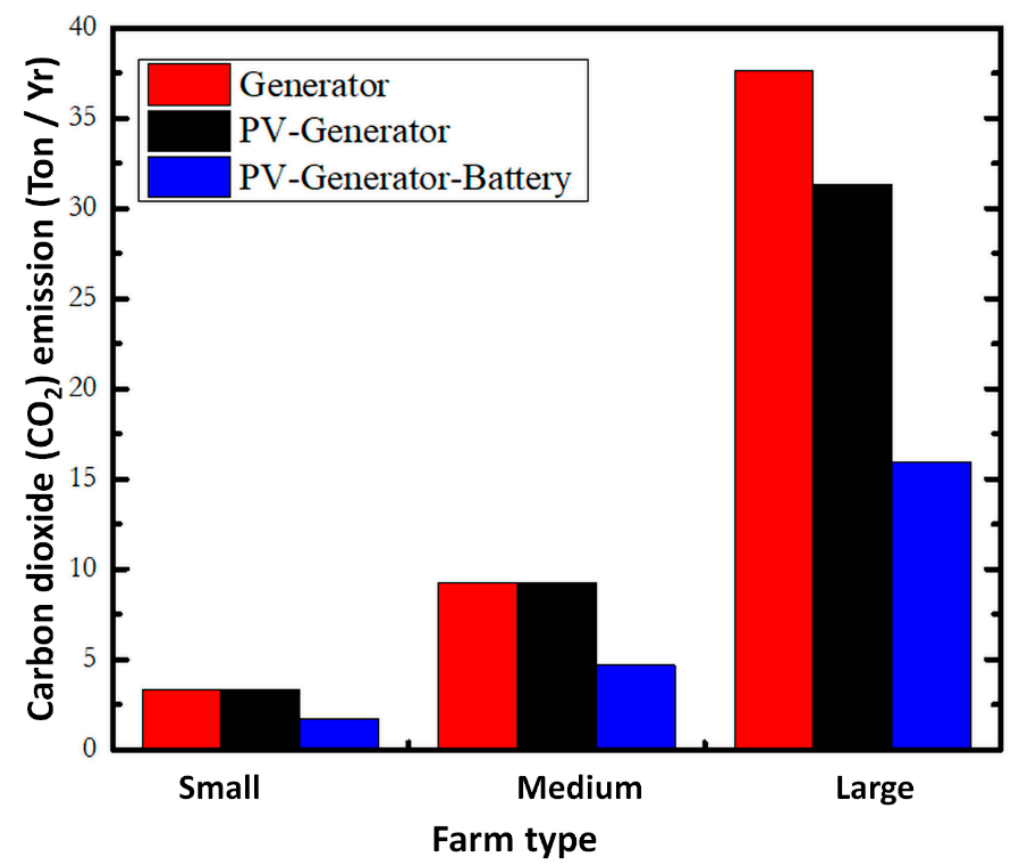

Figure 11. Carbon dioxide emission from different types of the farms for different energy sources.

\section{Discussion}

From the simulation results, we would like to state the following remarks about this study:

* In this study, the LCOE for small-, medium- and large-sized farms are 0.451, 0.467 and $0.508 \$ \mathrm{USD} / \mathrm{kWh}$, respectively. It can be concluded here that medium- and small-sized farms are more feasible than the large farms in rural areas for off-grid power supply systems.

* The total cost for PV, generator and battery hybrid system is lower than the generator only or PV and battery system. On the other hand, PV, generator and battery hybrid systems significantly reduce greenhouse gas emissions. Therefore, the PV, generator and battery hybrid system are economically and environmentally feasible for off-grid power generation in rural areas of Bangladesh.

- A cattle farm is more convenient if its size is synchronized with the local market because, if it requires time for trading the milk, it needs to be stored in a refrigerator. As a result of the proposed $\mathrm{PV}$, generator and battery hybrid system may not be ideal due to high load demand. 
* Though the capital cost and initial investment is very high for large farm compare with the small- or medium-type farms, the payback period for small and medium farms are 4.7 and 4.6 years, respectively. If the government provides some subsidies, then the payback period will reduce significantly.

* According to the current local market, fuel price is \$USD 0.77/L which may have a great impact on the LCOE confirmed by several studies, as reported in Refs. [56,57], that is based on the diesel price $(0.2-0.5 \$ \mathrm{USD} / \mathrm{L})$; the LCOE is found in the range of $0.22-0.35 \$ \mathrm{USD} / \mathrm{kWh}$.

In addition, the energy demand per cow for the small and medium farm is almost the same; however, for large-scale cattle farming, nearly $25 \%$ extra energy is required, as shown in Figure 12. This is because of the automation of collecting and storing milk for trading some distance place. As a result, the energy consumption per cow increase and the LOCE increases. Since per capita energy consumption is big for the large scale farm due to storing milk, the small- and medium-scale cattle farming is feasible from the economic point of view where the production is only for the local market.

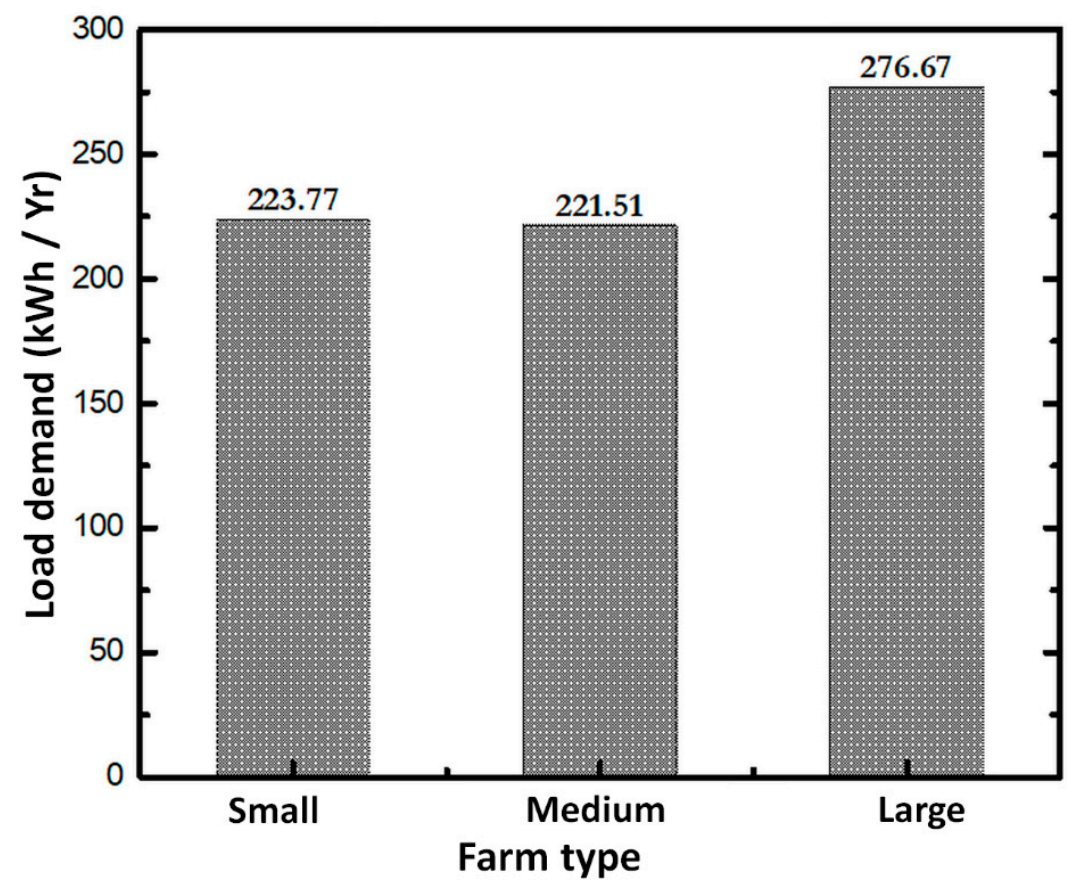

Figure 12. Load demand for a single cow depending on the farm size.

\section{Conclusions}

We demonstrated the design and optimization of hybrid power system together with the addition of thin-film, Low-E coating assisted power-saving feature for next-generation cultivation and farming system. From the obtained hybrid energy system optimization results, we found the energy payback period for small and medium farms are 4.7 and 4.6 years, respectively; however, if the farm size is larger, this payback period could be 3.5 years. Note that during the hybrid energy system simulation the advantage of thin-film Low-E-type coatings was not accounted for. In summary, we can comment that our study of energy engineering together with the advanced building material coatings will be the model for modern farming in any rural areas, and will help to reduce the carbon emission footprint for any other countries as well.

Author Contributions: Conceptualization, M.N.-E-A.; methodology M.N.-E-A., M.N.H.; software, M.N.-E-A., and M.N.H.; validation, M.N.-E-A., M.N.H., S.M.A., M.K.B., and N.D.; formal analysis, M.N.-E-A., M.N.H., S.M.A., and M.K.B.; investigation, M.N.-E-A., M.N.H.; resources, M.N.-E-A., and M.N.H.; data curation, M.N.-E-A., M.N.H., and M.K.B.; writing — original draft preparation, M.N.-E-A., and M.N.H.; writing—review and editing, M.N.-E-A., M.N.H., S.M.A., M.K.B., and N.D.; visualization, M.N.-E-A., M.N.H., S.M.A., and M.K.B.; supervision, 
M.N.-E-A.; project administration, M.N.-E-A. All authors have read and agreed to the published version of the manuscript.

Funding: This research received no external funding.

Conflicts of Interest: The authors declare no conflict of interest.

\section{References}

1. Bangladesh Economic Review 2018-2019, Ministry of finance, Government of Bangladesh (GoB). Available online: www.mof.gov.bd (accessed on 20 August 2020).

2. Roy, D.; Dev, D.S.; Sheheli, S. Food Security in Bangladesh: Insight from Available Literature. J. Nutr. Food Secur. 2019, 4, 66-75. [CrossRef]

3. Livestock Economy at a Glance 2018-19, Department of Livestock Services (DLS), Government of Bangladesh (GOB). Available online: www.dls.gov.bd (accessed on 20 August 2020).

4. Nisbett, N.; Davis, P.; Yosef, S.; Akhtar, N. Bangladesh's story of change in nutrition: Strong improvements in basic and underlying determinants with an unfinished agenda for direct community level support. Glob. Food Secur. 2017, 13, 21-29. [CrossRef]

5. Bishwajit, G.; Barmon, R.; Ghosh, S. Reviewing the status of agricultural production in bangladesh from a food security perspective. Russ. J. Agric. Socio-Economic Sci. 2014, 25, 19-27. [CrossRef]

6. The Business Standard report “Decision to import meat will be suicidal”. Available online: https://tbsnews. net/bangladesh/decision-import-meat-will-be-suicidal. (accessed on 16 October 2020).

7. Manandhar, A.; Milindi, P.; Shah, A. An overview of the post-harvest grain storage practices of smallholder farmers in developing countries. Agriculture 2018, 8, 57. [CrossRef]

8. Kumar, D.; Kalita, P. Reducing Postharvest Losses during Storage of Grain Crops to Strengthen Food Security in Developing Countries. Foods 2017, 6, 8. [CrossRef]

9. Pekmez, H. Cereal storage techniques: A review. J. Agric. Sci. Technol. B 2016, 6, 67-71. [CrossRef]

10. On-Farm-Cold-Storage. Available online: https://fruit.triforce.cals.wisc.edu/wp-content/uploads/sites/36/ 2017/02/On-Farm-Cold-Storage.pdf (accessed on 30 August 2020).

11. Thomas, J.A.; Vasiliev, M.; Nur-E-Alam, M.; Alameh, K. Investigation of the optimum illumination spectrum for maximizing the energy savings and yield of Lactuca sativa, L. in glass greenhouses. Sustainability 2020, 12, 3740. [CrossRef]

12. Patel, K.; Das, N.; Khan, M.M.K. Optimization of hybrid solar, wind and diesel energy systems from economic point of view. In Proceedings of the 29th Australasian Universities Power Engineering Conference (AUPEC), Nadi, Fiji, 26-29 November 2019.

13. Tan, Y.; Meegahapola, L.; Muttaqi, K.M. A review of technical challenges in planning and operation of remote area power supply systems. Renew. Sustain. Energy Rev. 2014, 38, 876-889. [CrossRef]

14. Linn, S.; Ya, A.Z. Solar/Wind/Diesel hybrid energy system with battery storage for rural electrification. Int. J. Sci. Eng. Tech. Res. 2014, 3, 2172-2176.

15. Robinson, P.; Gowda, A.C.; Sameer, S.; Patil, S. Development of renewable energy based hybrid system for electricity generation-A case study. Int. J. Latest Tech. Eng. Manag. Appl. Sci. 2017, 6, 2278-2540.

16. Akikur, R.K.; Saidur, R.; Ping, H.W.; Ullah, K.R. Comparative study of stand-alone and hybrid solar energy systems suitable for off-grid rural electrification: A review. Renew. Sustain. Energy Rev. 2013, 27, 738-752. [CrossRef]

17. Mohamed, M.A.; Eltamaly, A.M.; Alolah, A.I. Sizing and techno-economic analysis of stand-alone hybrid photovoltaic/wind/diesel/battery power generation systems. J. Renew. Sustain. Energy 2015, 7, 063128. [CrossRef]

18. Karim, M.E.; Karim, R.; Islam, M.T.; Muhammad-Sukki, F.; Bani, N.A.; Muhtazaruddin, M.N. Renewable Energy for Sustainable Growth and Development: An Evaluation of Law and Policy of Bangladesh. Sustainability 2019, 11, 5774. [CrossRef]

19. Sustainable and Renewable Energy Development Authority, Department of Power Ministry of Power, Energy and Mineral Resources, Government of the People's Republic of Bangladesh. Available online: http://www.sreda.gov.bd/index.php/site/page/7b9b-49f7-69fb-40fd-45a3-9e6c-b391-7ba5-31f9-13ee (accessed on 9 October 2020). 
20. Mollik, S.; Rashid, M.M.; Hasanuzzaman, M.; Karim, M.E.; Hosenuzzaman, M. Prospects, progress, policies, and effects of rural electrification in Bangladesh. Renew. Sustain. Energy Rev. 2016, 65, 553-567. [CrossRef]

21. Ministry of Power, Energy and Mineral Resources (MPEMR). Policy Guidelines for Small Power Plants in Private Sector; MPEMR: Dhaka, Bangladesh, 1996.

22. Bangladesh Energy Regulatory Commission. Bangladesh Energy Regulatory Commission (Tariff for Roof Top Solar PV Electricity) Regulations, 2016 (Draft); Bangladesh Energy Regulatory Commission: Dhaka, Bangladesh, 2016. Available online: http://berc.portal.gov.bd/sites/default/files/files/berc.portal.gov.bd/page/a250b6fc_ 8bcf_4c96_bb20_3c3de230467a/berc_tariff_regulations_rooftof_solar\%28draft\%29.pdf (accessed on 9 October 2020).

23. World Health Organization (WHO). 2020. Available online: https://www.who.int/indonesia/news/detail/ 08-03-2020-knowing-the-risk-for-covid-19\#: \{\}:text=People\%20who\%20are\%20aged\%20over,infected \% 20with\%20the\%20virus (accessed on 20 August 2020).

24. World Health Organization (WHO). $2020 . \quad$ Available online: https://www.who. int/emergencies/diseases/novel-coronavirus-2019/advice-for-public/myth-busters?gclid=

EAIaIQobChMIsOGxvYTM6gIVyhErCh0swgmPEAAYASAAEgKbM_D_BwE\#climate (accessed on 20 August 2020).

25. Trade Set to Plunge as COVID-19 Pandemic Upends Global Economy. Available online: https://www.wto. org/english/news_e/pres20_e/pr855_e.htm (accessed on 31 August 2020).

26. Coronavirus Update: Industry Fast Facts, by IBISWorld. 1 June 2020. Available online: https://www. ibisworld.com/industry-insider/coronavirus-insights/coronavirus-update-industry-fast-facts/ (accessed on 2 September 2020).

27. Live-blog: How the Coronavirus Affects Garment Workers In Supply Chains. Available online: https://cleanclothes.org/news/2020/live-blog-on-how-the-coronavirus-influences-workers-in-supplychains (accessed on 2 September 2020).

28. COVID-19 Challenges for the Indian Economy: Trade and Foreign Policy Effects. Available online: https://www.eepcindia.org/eepc-download/617-Covid19_Report.pdf (accessed on 2 September 2020).

29. COVID-19: Impacts on Australia's Food and Agribusiness Sector. Available online: https://home.kpmg/au/ en/home/insights/2020/03/coronavirus-covid-19-impact-on-food-agribusiness-sector.html (accessed on 2 September 2020).

30. Shimanta, M.L.R.; Gope, H.; Sumaiya, I.J. Readymade Garments Sector and COVID-19 in Bangladesh. Preprints 2020. [CrossRef]

31. World Health Organization (WHO), 2020; COVID-19 and Food Safety: Guidance for Competent Authorities Responsible for National Food Safety Control Systems. 2020. Available online: https://www.who.int/publications/i/item/covid-19-and-food-safety-guidance-forcompetent-authorities-responsible-for-national-food-safety-control-systems (accessed on 20 August 2020).

32. COVID-19 and Food Safety: Guidance for competent authorities responsible for national food safety control systems. Available online: http://agriculture.vic.gov.au/agriculture/dairy/energy-in-dairy/solarpanel-systems-for-the-dairy-shed (accessed on 10 August 2020).

33. Agriculture Victoria. Available online: http://agriculture.vic.gov.au/agriculture/dairy/energy-in-dairy/solarpanel-systems-for-the-dairy-shed (accessed on 10 August 2020).

34. Mbow, C.C.; Rosenzweig, L.G.; Barioni, T.G.; Benton, M.; Herrero, M.; Krishnapillai, E.; Liwenga, P.; Pradhan, M.G.; Rivera-Ferre, T.; Sapkota, F.N.; et al. Food Security. In Climate Change and Land: An IPCC Special Report on Climate Change, Desertification, Land Degradation, Sustainable Land Management, Food Security, and Greenhouse Gas Fluxes in Terrestrial Ecosystems; Shukla, P.R., Skea, J., Calvo Buendia, E., Masson-Delmotte, V., Pörtner, H.-O., Roberts, D.C., Zhai, P., Slade, R., Connors, S., van Diemen, R., et al., Eds.; IPCC: Geneva, Switzerland, 2019; in press; Available online: https://www.ipcc.ch/srccl/chapter/chapter-5/ (accessed on 10 August 2020).

35. The Business Standard report "The impact of COVID-19 on the dairy industry of Bangladesh". Available online: https://tbsnews.net/thoughts/impact-covid-19-dairy-industry-bangladesh-68569 (accessed on 11 August 2020). 
36. World Economic Forum report "How Bangladesh's leaders should respond to the economic threats of COVID-19". Available online: https:/www.weforum.org/agenda/2020/04/covid-19-coronavirus-bangladesh/ (accessed on 12 August 2020).

37. Bdnews24.com "Dairy farmers hit hard by coronavirus lockdown in Bangladesh". Available online: https://bdnews24.com/bangladesh/2020/04/13/dairy-farmers-hit-hard-by-coronavirus-lockdownin-bangladesh (accessed on 10 August 2020).

38. Nur-E-Alam, M. Can Energy Engineering be a Hope for the Post COVID-19 Bangladesh. Innovate July 2020/25. Available online: https://issuu.com/iceaus/docs/innovate-icea_july_2020?fr=sNTE1NzE2OTYyNTA\&fbclid= IwAR3ONzUf6ORRz-T-gDRrHOsxJSJvniiREH5BmZ1IZRmyM5Tk1_qrkg-vW90 (accessed on 16 October 2020).

39. Momtaj, I.A.; Nur-E-Alam, M. Sweatshops Workers in post COVID-19. Innovate July 2020/48. Available online: https:/issuu.com/iceaus/docs/innovate-icea_july_2020?fr=sNTE1NzE2OTYyNTA\&fbclid= IwAR3ONzUf6ORRz-T-gDRrHOsxJSJvniiREH5BmZ1IZRmyM5Tk1_qrkg-vW90 (accessed on 16 October 2020).

40. Begum, M.; Farid, M.S.; Barua, S.; Alam, M.J. COVID-19 and Bangladesh: Socio-economic analysis towards the future correspondence. Preprints 2020, 2020040458. [CrossRef]

41. Poultry Sector Stares at over Tk1,150 Crore Losses. Available online: https://tbsnews.net/economy/industry/ poultry-sector-stares-over-tk1150-crore-losses-63472 (accessed on 2 September 2020).

42. Sunny, A.R.; Sazzad, S.A.; Datta, G.C.; Sarker, A.K.; Ashrafuzzaman, M.; Prodhan, S.H. Assessing impacts of COVID-19 on aquatic food system and small-scale fisheries in Bangladesh. Preprints 2020. [CrossRef]

43. Dalapati, G.K.; Kushwaha, A.K.; Sharma, M.; Suresh, V.; Shannigrahi, S.; Zhuk, S.; Masudy-Panah, S. Transparent heat regulating (THR) materials and coatings for energy saving window applications: Impact of materials design, micro-structural, and interface quality on the THR performance. Prog. Mater. Sci. 2018, 95, 42-131. [CrossRef]

44. Leftheriotis, G.; Yianoulis, P.; Patrikios, D. Deposition and optical properties of optimised ZnS/Ag/ZnS thin films for energy saving applications. Thin Solid Films 1997, 306, 92-99. [CrossRef]

45. Pracchia, J.A.; Simon, J.M. Transparent heat mirrors: influence of the materials on the optical characteristics. Appl. Opt. 1981, 20, 251-258. [CrossRef]

46. Kulczyk-Malecka, J.; Kelly, P.; West, G.; Clarke, G.; Ridealgh, J.; Almtoft, K.; Greer, A.; Barber, Z. Investigation of silver diffusion in TiO2/Ag/TiO2 coatings. Acta Mater. 2014, 66, 396-404. [CrossRef]

47. Vasiliev, M.; Nur-E-Alam, M.; Alameh, K. Highly stable thin-film multilayers for thermal regulation and energy savings in smart cities. In Proceedings of the 2019 IEEE 16th International Conference on Smart Cities: Improving Quality of Life Using ICT, IoT \& AI, Charlotte, NC, USA, 6-9 October 2019.

48. Hossen, M.; Hossain, M.; Abedin, M.; Karim; Rume, F. Animal Production Strategies in Southern Region of Bangladesh. Agriculturists 2010, 6, 77-83. [CrossRef]

49. Expert System for Cattle and Buffalo. Available online: http://www.agritech.tnau.ac.in/expert_system/ cattlebuffalo/Housing\%20Management\%20of\%20Cattle\%20and\%20Buffalo.html\#plan (accessed on 23 August 2020).

50. Keown, J.F.; Kononoff, P.J.; Grant, R.J. How to Reduce Heat Stress in Dairy Cattle. Historical Materials from University of Nebraska-Lincoln Extension; Nebraska Extension: Lincoln, NE, USA, 2005; p. G05-1582.

51. Todde, G.; Murgia, L.; Caria, M.; Pazzona, A. A multivariate statistical analysis approach to characterize mechanization, structural and energy profile in Italian dairy farms. Energy Rep. 2016, 2, 129-134. [CrossRef]

52. Alahmer, A.; AlSaqoor, S. Design of a dairy cooling thermal storage supported with secondary refrigeration cooling unit. IOSR J. Mech. Civ. Eng. 2014, 11, 30-36. [CrossRef]

53. Cengel, Y. Heat and Mass Transfer: A Practical Approach, 3rd ed.; McGraw-Hill: New York, NY, USA, 2006.

54. Upton, J.; Humphreys, J.; Koerkamp, P.G.; French, P.; Dillon, P.; De Boer, I.J.M. Energy demand on dairy farms in Ireland. J. Dairy Sci. 2013, 96, 6489-6498. [CrossRef] [PubMed]

55. Nur-E-Alam, M.; Vasiliev, M.; Alameh, K. Dielectric/Metal/Dielectric (DMD) Multilayers: Growth and Stability of Ultra-Thin Metal Layers for Transparent Heat Regulation (THR); Elsevier BV: Amsterdam, The Netherlands, 2020; pp. 83-112. 
56. Aziz, A.S.; Tajuddin, M.F.N.; Adzman, M.R.; Ramli, M.A.M.; Mekhilef, S. Energy Management and Optimization of a PV/Diesel/Battery Hybrid Energy System Using a Combined Dispatch Strategy. Sustainability 2019, 11, 683. [CrossRef]

57. Abd-El Mageed, H.S. Cost analysis and optimal sizing of PV-Diesel hybrid energy systems. Am. J. Renew. Sustain. Energy 2018, 4, 47-55.

Publisher's Note: MDPI stays neutral with regard to jurisdictional claims in published maps and institutional affiliations.

(C) 2020 by the authors. Licensee MDPI, Basel, Switzerland. This article is an open access article distributed under the terms and conditions of the Creative Commons Attribution (CC BY) license (http://creativecommons.org/licenses/by/4.0/). 